\title{
A survey on the knowledge and perception of computer assisted learning among undergraduate medical students in a tertiary care teaching institute of North India
}

\author{
Amita Jindal, Raj Kumar*, Nagma Bansal, Kamalpreet Kaur
}

Department of Pharmacology, GGS Medical College (BFUHS), Faridkot, Punjab, India

Received: 18 February 2018 Accepted: 28 March 2018

*Correspondence to:

Dr. Raj Kumar,

Email: anurajkumar76@ gmail.com

Copyright: () the author(s), publisher and licensee Medip Academy. This is an openaccess article distributed under the terms of the Creative Commons Attribution NonCommercial License, which permits unrestricted noncommercial use, distribution, and reproduction in any medium, provided the original work is properly cited.

\begin{abstract}
Background: Computer assisted learning (CAL) in the classroom as well as laboratory in the medical profession has been rising in the present scenario worldwide. CAL can replace laboratory based animal experiments to a large extent and prevent the unnecessary harm or killing of animals. In India, only few studies have been conducted on CAL till date. Aims and objective of the study was to evaluate the knowledge and perception on CAL among undergraduate medical students.

Methods: This cross sectional study was carried out on the medical students (MBBS-Second Professional) in the department of pharmacology at Guru Gobind Singh Medical College and Hospital, Faridkot, Punjab, India. Feedback was obtained from 105 students who had already performed animal experiments in CAL laboratory.

Results: It was seen that Computer simulated models (CSMs) are useful for undergraduate teaching (by 98.1\%), CAL enrich learning experience about drug effects (by 97.1\%), CSMs in CAL is user friendly (by 97.1\%) and use of CSMs in teaching is ethical (by $97.1 \%$ ).

Conclusions: CAL is an innovative teaching and learning technique for the medical students. This is an effective mode of teaching pharmacology to the students and it also helps the students to apply their theoretical knowledge of drugs to the practical aspects (without use of animal) on computer simulated models.
\end{abstract}

Keywords: Alternated to animal experiments, CAL (Computer assisted learning), CSMs (Computer simulated models)

\section{INTRODUCTION}

Computer assisted learning in the classroom as well as laboratory in the medical profession has been rising in the present scenario worldwide. In the recent years, the use of animals for teaching and learning of basic medical sciences has shown a downward trend over the last decade. ${ }^{1-5}$ The main reason behind this is the ethical concerns with the use of animals for undergraduate training and secondly advancement in the field of information technology in the $20^{\text {th }}$ century which contributed significantly to this trend.
Laboratory based animal experiments are replaced by computer assisted learning (CAL) which is now being used as an effective teaching and learning tool. ${ }^{6,7} \mathrm{CAL}$ in the medical education has been implemented by $95 \%$ of medical schools in the United States and $100 \%$ across medical schools in Canada and United Kingdom. But in India, only few of the medical colleges have adopted this new technique for undergraduate teaching. ${ }^{3,4,8,9}$ Although use of animals for research purposes is inevitable, the same may not be the case for teaching and learning. Ethical concerns have been raised for the use of animals purely for learning purpose. ${ }^{10} \mathrm{CAL}$ can replace laboratory based 
animal experiments to a large extent and prevent the unnecessary harm or killing of animals. ${ }^{11}$ Regulators of medical education across the world have been expressing their concern for this issue. Recently, Medical Council of India has issued guidelines underlining that at undergraduate level, animal experiments need not be performed and instead use of CAL should be incorporated. ${ }^{12}$

In India, only few studies have been conducted on CAL till date. So this study was done in tertiary care hospital of north India to evaluate the knowledge and perception on CAL among undergraduate medical students. This study also aims at in finding out if the medical students like CAL as a useful learning method in the teaching.

The objective of this study was to assess the knowledge and perception of undergraduate students on CAL.

\section{METHODS}

This cross sectional study was carried out in the department of pharmacology at Guru Gobind Singh Medical College and Hospital, Faridkot, Punjab, India. Animal experiment simulated software (Elsevier Pvt. Ltd.) and other infrastructures to run this lab are available in the pharmacology department. 105 students of MBBS (Second Professional) were recruited in the study and feedback was obtained from these students. These students had already performed experiments in CAL laboratory after a brief demonstration given by the teachers. Feedback questionnaire was prepared containing 40 questions regarding CAL and got validated from the field expert. 29 questions had options in the form of yes or no while rest of the questions had more options to answer.

\section{Inclusion and exclusion criteria}

Students of MBBS (Second Professional) course who attended the theory classes of ANS (Autonomic Nervous System), CVS (Cardiovascular System), GIT (Gastrointestinal Tract) and the demonstration classes (in the Practical session) taken by the faculty and also performed all the exercises of CSMs in the CAL Lab were included. Students who were enrolled and remained absent during demonstration classes but attended the revision classes and practical sessions of CSMs were also included. While the students who remained absent in the theory as well as demonstration classes and those who had not performed all the practical exercises of CSMs were excluded from the study.

\section{RESULTS}

\section{Results on knowledge assessment}

Feedback questionnaire forms were filled by 105 students. Data of the study was analysed by keeping in mind the answers given by the students and number of students respond to each question. The data were entered in the excel sheets and results were tabulated in the form of mean percentage. $100 \%, 87 \%$ and $91 \%$ of students were aware of abbreviation of CAL, CPCSEA (Committee for the Purpose of Control and Supervision of Experiments on Animals) and PETA (People for the Ethical Treatment of Animals) respectively. $83 \%$ of students knew about 4Rs (Replacement, reduction, refinement and rehabilitation) regarding animal experiments.

After performing Computer Simulated Models (CSMs) experiments, pharmacology was found more interesting by $67 \%$ of students (Table 1). According to $36 \%$ of students, time period provided to perform an exercise on CSM should be 20-25 minutes. Teacher student ratio in CAL was appropriate (1:4) according to $67 \%$ of students. However, maximum number of students $(68 \%)$ felt that 2 students should perform on a single computer for better understanding of the animal experiment and its result. Most understandable CSMs were rabbit eye experiment followed by $\operatorname{dog} \mathrm{BP}$, bioassay and frog rectus by $70 \%$, $22 \%, 6 \%$ and $2 \%$ of the students respectively. According to $58 \%$ of students, understanding of Autonomic Nervous System (ANS) was made easy with CSMs (Table 1).

\section{DISCUSSION}

Computer assisted learning in experimental pharmacology plays a pivotal role in the scholastic achievement of students by helping them to develop a positive attitude towards basic sciences in the medical profession. It becomes necessary to assess the attitude of the students regarding this new lab (CAL) in the paraclinical/ medical curriculum as an alternative to the real animal experiments.

In this study authors found that CSMs increased the understanding of theoretical concepts, reinforced the theoretical lectures and improved understanding of action of drugs. Majority of students felt that CAL is self directed learning. With CAL, the students get the advantage to learn at their convenience and pace of learning becomes faster; it can save faculty time as well as resources.

Authors analysed that majority of the students are afraid of handling animals. CSMs are easy to use by these students with better learning. It also helps the students to perform difficult experiments on CSMs without harming and loosing animals by using CAL lab.

Majority of students felt that understanding of ANS topics was greatly increased with CSMs. This might be attributed to the fact that the use of CSMs increases the interest of students and also helps the students to make the difficult subject an easy one, thus enhances rational thinking about the difficult subjects / topics of pharmacology.

In this study, according to $97.1 \%$ of the students CAL increases the understanding of the drug effects (pharmacodynamic actions), which is in concordant with the other studies (Table 2). ${ }^{9,13,14}$ 
Table 1: Results on perception of students on computer assisted learning.

\begin{tabular}{|c|c|c|c|c|c|c|}
\hline $\begin{array}{l}\text { The outcomes of computer simulated } \\
\text { pharmacology experiments }\end{array}$ & $\begin{array}{l}\text { Number of } \\
\text { students } \\
\text { with } \\
\text { positive } \\
\text { response }\end{array}$ & $\begin{array}{l}\text { Number of } \\
\text { students } \\
\text { with } \\
\text { negative } \\
\text { response }\end{array}$ & $\begin{array}{l}\text { Number } \\
\text { of } \\
\text { students } \\
\text { with no } \\
\text { response }\end{array}$ & $\begin{array}{l}\% \text { of } \\
\text { students } \\
\text { with } \\
\text { positive } \\
\text { response }\end{array}$ & $\begin{array}{l}\% \text { of } \\
\text { students } \\
\text { with } \\
\text { negative } \\
\text { response }\end{array}$ & $\begin{array}{l}\% \text { of } \\
\text { students } \\
\text { with no } \\
\text { response }\end{array}$ \\
\hline $\begin{array}{l}\text { Animal should be used to demonstrate drug } \\
\text { effects in experiment }\end{array}$ & 19 & 86 & 0 & 18.1 & 81.9 & 0 \\
\hline $\begin{array}{l}\text { CAL enrich learning experience about drug } \\
\text { effects }\end{array}$ & 102 & 2 & 1 & 97.1 & 1.9 & 0.9 \\
\hline Reinforcement of lectures with CAL & 73 & 17 & 15 & 69.5 & 16.2 & 14.3 \\
\hline $\begin{array}{l}\text { CSM (Computer Simulated Models) in CAL } \\
\text { is user friendly }\end{array}$ & 102 & 3 & 0 & 97.1 & 2.8 & 0 \\
\hline $\begin{array}{l}\text { Any technical difficulty while doing } \\
\text { experiment }\end{array}$ & 19 & 86 & 0 & 18.0 & 81.9 & 0 \\
\hline $\begin{array}{l}\text { Time provided to students for experiment on } \\
\text { CSM (Computer Simulated Models) was } \\
\text { sufficient }\end{array}$ & 41 & 64 & 0 & 39.0 & 60.9 & 0 \\
\hline $\begin{array}{l}\text { CAL experiment is easy to remember than } \\
\text { experiments on live animals }\end{array}$ & 63 & 38 & 4 & 60.0 & 36.2 & 3.8 \\
\hline $\begin{array}{l}\text { Recommend these CAL experiments to other } \\
\text { medical students }\end{array}$ & 101 & 4 & 0 & 96.2 & 3.8 & 0 \\
\hline $\begin{array}{l}\text { Recommend these CAL experiments to other } \\
\text { departments of medical college }\end{array}$ & 94 & 11 & 0 & 89.5 & 10.5 & 0 \\
\hline Written instructions in CAL are helpful & 98 & 7 & 0 & 93.3 & 6.7 & 0 \\
\hline Appropriate teacher student ratio in CAL & 70 & 35 & 0 & 66.7 & 33.3 & 0 \\
\hline $\begin{array}{l}\text { Clearly visualized and easily understandable } \\
\text { drug response in CSM }\end{array}$ & 91 & 12 & 2 & 86.7 & 11.4 & 1.9 \\
\hline $\begin{array}{l}\text { Pretest and posttest given in each experiment } \\
\text { of CAL are helpful }\end{array}$ & 90 & 11 & 4 & 85.7 & 10.5 & 3.8 \\
\hline $\begin{array}{l}\text { Observations can be repeated in a short time } \\
\text { in CAL as comparison to traditional live } \\
\text { experiments }\end{array}$ & 96 & 7 & 2 & 91.4 & 6.7 & 1.9 \\
\hline $\begin{array}{l}\text { Difficult experiments can be demonstrated } \\
\text { with ease in CAL lab }\end{array}$ & 95 & 9 & 1 & 90.5 & 8.6 & 0.9 \\
\hline CAL is self directed learning & 83 & 21 & 1 & 79.0 & 20 & 0.9 \\
\hline $\begin{array}{l}\text { CAL increase the interaction of students with } \\
\text { teachers }\end{array}$ & 81 & 22 & 2 & 77.1 & 20.9 & 1.9 \\
\hline $\begin{array}{l}\text { CAL is an easy escape for the students who } \\
\text { have a phobia of animal handling }\end{array}$ & 99 & 6 & 0 & 94.3 & 5.7 & 0 \\
\hline $\begin{array}{l}\text { Prefixed doses in CAL hinder to observe } \\
\text { biological response at desired doses }\end{array}$ & 61 & 42 & 2 & 58.1 & 40 & 1.9 \\
\hline $\begin{array}{l}\text { Conscience of students allow animal } \\
\text { experiments for skill and training }\end{array}$ & 33 & 70 & 2 & 31.4 & 66.7 & 1.9 \\
\hline CSMs useful for undergraduate teaching & 103 & 3 & 1 & 98.1 & 2.8 & 0.9 \\
\hline Use of CSM in teaching is ethical & 102 & 2 & 1 & 97.1 & 1.9 & 0.9 \\
\hline Use of CSM in teaching is economical & 92 & 8 & 5 & 87.6 & 7.6 & 4.8 \\
\hline $\begin{array}{l}\text { CAL/ CSMs clearly convey the required } \\
\text { details on animal experiments }\end{array}$ & 82 & 23 & 0 & 78.1 & 21.9 & 0 \\
\hline $\begin{array}{l}\text { Simulation/ responses adequately enriched } \\
\text { with video demonstration and illustration in } \\
\text { CSMs. }\end{array}$ & 81 & 18 & 6 & 77.1 & 17.1 & 5.7 \\
\hline CSM is highly interactive & 78 & 26 & 1 & 74.3 & 24.8 & 0.9 \\
\hline $\begin{array}{l}\text { CSM is full of animated sequence that make } \\
\text { simulation appear to be realistic }\end{array}$ & 77 & 26 & 2 & 73.3 & 24.8 & 1.9 \\
\hline CAL lab well equipped & 87 & 16 & 2 & 82.8 & 15.2 & 1.9 \\
\hline $\begin{array}{l}\text { CSMs should be made compulsory in } \\
\text { undergraduate curriculum }\end{array}$ & 89 & 4 & 12 & 84.8 & 3.8 & 11.4 \\
\hline
\end{tabular}


Table 2: Comparison of findings with other studies regarding student's opinion of computer assisted learning.

\begin{tabular}{|c|c|c|c|c|c|c|c|c|c|}
\hline Parameters & $\begin{array}{l}\text { Present } \\
\text { study }\end{array}$ & $\begin{array}{l}\text { Kuruvilla } \\
\text { A et } \mathbf{a l}^{\mathbf{3}}\end{array}$ & $\begin{array}{l}\text { Govindraj } \\
\text { C et al }{ }^{13}\end{array}$ & $\begin{array}{l}\text { Sewell } \\
\text { RDE et } \\
\text { all }^{16}\end{array}$ & $\begin{array}{l}\text { Brain } \\
\text { S et } \\
\text { al }^{17}\end{array}$ & $\begin{array}{l}\text { Badyal } \\
\text { DK et } \\
\text { al }^{9}\end{array}$ & $\begin{array}{l}\text { Leatherd } \\
\text { HL et al }{ }^{15}\end{array}$ & $\begin{array}{l}\text { Dewhurst } \\
\text { et } \mathbf{a l}^{18}\end{array}$ & $\begin{array}{l}\text { Wang } \\
\text { L et } \\
\text { al }^{14}\end{array}$ \\
\hline $\begin{array}{l}\text { No. of students } \\
\text { enrolled (n) }\end{array}$ & 105 & 141 & 127 & 99 & 78 & 47 & 156 & 6 & 75 \\
\hline $\begin{array}{l}\text { Improves } \\
\text { understanding of } \\
\text { drug effects/ } \\
\text { subject }\end{array}$ & $97 \%$ & - & $75 \%$ & yes & Yes & $74.47 \%$ & Yes & yes & $98.7 \%$ \\
\hline $\begin{array}{l}\text { Self directed } \\
\text { learning }\end{array}$ & $79 \%$ & - & - & yes & Yes & yes & $>66 \%$ & - & - \\
\hline $\begin{array}{l}\text { Better teacher } \\
\text { student } \\
\text { interaction }\end{array}$ & $77 \%$ & - & - & - & - & - & $>50 \%$ & yes & - \\
\hline $\begin{array}{l}\text { Animal } \\
\text { experiments easy } \\
\text { to remember } \\
\text { with CSMs }\end{array}$ & $60 \%$ & $16 \%$ & $70 \%$ & - & - & - & $>66 \%$ & yes & - \\
\hline $\begin{array}{l}\text { Repeated } \\
\text { observations } \\
\text { without animal } \\
\text { loss }\end{array}$ & $91.4 \%$ & $9 \%$ & $90 \%$ & yes & - & yes & Yes & - & - \\
\hline $\begin{array}{l}\text { Difficult } \\
\text { experiments } \\
\text { demonstrated }\end{array}$ & $90 \%$ & $24 \%$ & $>80 \%$ & - & - & - & - & - & - \\
\hline Prefixed doses & $58 \%$ & $18 \%$ & $>80 \%$ & - & - & - & - & - & - \\
\hline
\end{tabular}

According to our study, experiments can be repeated easily with CSMs $(91.4 \%)$ which is concordant with the other studies. ${ }^{9,13,15,16}$

More than half of the students in the study mentioned about prefixed doses in CSM experiments. The reason for the prefixed doses is to stress on the specific pharmacological actions of drugs on receptors but students cannot observe biological response at different doses due to prefixed doses.

However, it has been noticed that better teacher student interaction $(77 \%)$ was more as reported by other study. ${ }^{15}$

Some students encountered some technical errors during the computer assisted learning sessions. Therefore, a good computer expert support precludes any such technical glitches.

Another issue raised by the students is that time provided to perform an exercise was not sufficient. According to majority of students, more time should be provided to perform exercises on CSMs. This might have happened due to less number of computers in CAL lab. This issue can be solved by increasing the number of computers so that every student can perform individually on a single computer for better understanding of the animal experiment exercises and could repeat the exercises on their own if he is unable to analyze the response of the $\operatorname{drug}(\mathrm{s})$.

CAL primarily focuses on increasing the understanding of subject rather than psychomotor skill acquisition. It improves understanding and learning experience about drug effects. Moreover, these experiments are easy to remember and to perform than experiments on live animals. These experiments with CSMs should be made compulsory in medical curriculum of undergraduate teaching for better understanding of the subject. Not only pharmacology, but other departments of medical college should also teach their students with CAL.

Hence forth, performing animal experiments with CSMs in CAL lab is a better alternative to teach the experimental pharmacology in a better and rational way. It also enhances the rational thinking regarding the animal experiments and their results. Keeping in view the feedback provided by the students it becomes necessary that authors should take steps to improve this new technique of learning experimental pharmacology. This would be only possible if Author increase the number of computers in CAL lab, reforming the animal experimental exercises by giving adequate demonstrations prior to exercises on the software. This will enhance the understanding about the virtual animal experiments in the students.

Limitation of this study is that authors had a small sample size as only one batch of second professional MBBS 
students was enrolled in it. Secondly, there is a chance of bias as these students had not seen the real animal experiments.

\section{Implication of this study}

It helps us to take steps to improve the CAL lab infrastructure and secondly it also helps the teacher to improve the demonstration part prior to CSMs exercises. It also acts as a role model to the other medical institutes so that they show interest to develop such kind of (the CAL) Lab in their medical colleges.

\section{CONCLUSION}

CAL lab is an innovative teaching method for the undergraduate medical students. Its CSMs are highly interactive, user friendly and have high adaptability. This is an effective mode of teaching pharmacology to MBBS students and it helps students to apply the theoretical knowledge of drugs to the practical sessions. Computer simulation models let students to learn at their own pace and with better understanding by keeping in mind the drug response or effects on the CSMs. Therefore, CAL is a better mode of teaching practical exercises on the virtual animal models.

\section{ACKNOWLEDGEMENTS}

Authors express their deep gratitude to Dr (Prof.) Raj Bahadur, Hon'able Vice-chancellor, BFUHS, Faridkot (Punjab) for his valuable support and who showed keen interest to get established a new Computer Assisted Learning (CAL) Lab in the Deptt. of Pharmacology, GGS Medical College, Faridkot. Authors are also thankful to Elsevier Pvt. Ltd. for providing us animal experiment simulated software and training to run this software.

\section{Funding: No funding sources}

Conflict of interest: None declared

Ethical approval: Not required

\section{REFERENCES}

1. Rahman SZ, Khan RA. Computer simulation models as replacement of animal experiments in teaching undergraduate pharmacology. In: Rahman SZ, Salman MT eds. Alternatives to animal experimentation in Pharmacology - A guide and manual. $3^{\text {rd }}$ ed. Aligarh: Ibn Sina Academy; 2014:13-20.

2. Badyal D. Introduction to experimental pharmacology. 1st ed. New Delhi: Jaypee Brothers Medical Publishers (P) Ltd; 2008:73-74.

3. Kuruvilla A, Ramalingam S, Bose AC, Shastri GV, Bhuvaneswari K, Amudha G. Use of computer assisted learning as an adjuvant to practical Pharmacology teaching: Advantages and limitations. Indian J Pharmacol. 2001;33:272-5.
4. Sharma R, Verma U, Kapoor B, Chopra VS. Novel teaching approaches in Pharmacology. JK Science. 2004;6:172-3.

5. Hansen LA, Boss GR. Use of live animals in the curricula of U.S. medical schools: Survey results from 2001. Acad Med 2002;77:1147-9.

6. Wiecha JM. Collaborative online learning (COL): A new distance education methods. Essential Drug Monitor. 2003;33:36.

7. Moss S. Computer technology in education. Pharm J 1993;251:491.

8. Baby LT, Kavalakkat JC, Abraham S, Sathianarayanan S. CAL: A modern tool for Pharmacology. Internet J of Medical Simulation. 2009;2:2.

9. Badyal DK, Modgill V, Kaur J. Computer simulation models are implementable as replacements for animal experiments. Altern Lab Anim. 2009;37:191-5.

10. Solanki D. Unnecessary and cruel use of animals for medical undergraduate training in India. J Pharmacol Pharmacother. 2010;1:59.

11. Badyal DK, Desai C. Animal use in pharmacology education and research: The changing scenario. Indian J Pharm. 2014;46:257-65.

12. Medical Council of India. Notification, New Delhi, the 18 March 2014. No. MCI-34(41)/2013-Med./64022. In The Gazette of India, Part III, Section 4, No. 19. New Delhi, India: Government of India Press. Available at: http://www.mciindia.org/Rulesand-

Regulation/Gazette\% 20Notifications\%20\%20Amendments/msr-50-100-150-200-250.pdf (Accessed 02.12.14)

13. Govindaraja C, Jaiprakash H, Annamalai C, Vedhavathy SS. Computer assiste learning: Perceptions and knowledge skills of undergraduate medical students in a Malaysian medical school. Natl J Physiol Pharm Pharmacol. 2011;1:63-7.

14. Wang L. Computer-simulated pharmacology experiments for undergraduate pharmacy students: Experience from an Australian university. Indian J Pharmacol. 2001;33:280-2.

15. Leathard HL, Dewhurst DG. Comparison of cost effectiveness of a computer assisted learning program with tutored demonstration to teach intestinal motility to medical students. ALT-J. 1995;3:118-25.

16. Sewell RD, Stevens RG, Lewis DJ. Pharmacology experimental benefits from the use of computer assisted learning. Am J Pharm Educ. 1996;60:303-7.

17. Brain S, Dewhurst D, Williams A. Evaluation of a computer-based learning program to support student learning in pharmacology ALT-J. 1999;7:37-45.

18. Dewhurst D. Computer-based alternatives to using animals in teaching physiology and pharmacology to undergraduate student. Altern Lab Anim. 2004;32:517-20.

Cite this article as: Jindal A, Kumar R, Bansal N, Kaur K. A survey on the knowledge and perception of computer assisted learning among undergraduate medical students in a tertiary care teaching institute of North India. Int J Basic Clin Pharmacol 2018;7:917-21. 